\title{
Short communication: Socio-psychological factors influencing dairy farmers' intention to adopt high-grain feeding in Brazil
}

\author{
P. G. L. Lima, ${ }^{1}$ J. C. Damasceno, ${ }^{1}$ J. A. R. Borges, ${ }^{2}$ G. T. dos Santos, ${ }^{1}$ and F. I. Bánkuti ${ }^{1 *}$ \\ ${ }^{1}$ Department of Animal Science, State University of Maringá, PR 87020-900, Brazil \\ ${ }^{2}$ Faculty of Administration, Accounting, and Economics, Federal University of Grande Dourados, MS 79825-070, Brazil
}

\begin{abstract}
This study aimed to apply the theory of planned behavior to determine the effects of attitude, perceived behavioral control, and subjective norms on the intention of dairy farmers toward high-grain feeding. Quantitative data were collected through interviews with 150 dairy farmers in Paraná, Brazil. Partial least squares structural equation modeling was used to analyze the data. We observed that farmers with a positive perception of grain feeding (attitude) and a positive perception of their ability to increase the use of grains (perceived behavioral control) had higher intention to increase grain feeding. Social pressure (subjective norm) had no effect on the intention to grain feed. These results can contribute to the development of public strategies and policies that encourage the use of high-grain diets in dairy farms.
\end{abstract}

Key words: concentrate, milk production, partial least squares, structural equation modeling, theory of planned behavior

\section{Short Communication}

The Brazilian dairy sector has national and international relevance. Brazil produced 33.5 million tonnes of milk in 2017 (IBGE, 2018), accounting for $4.13 \%$ of the global production. Dairy farms play crucial economic and social roles in Brazil (Rocha et al., 2018). Small-scale dairy production systems are predominant in the country and are generally associated with low productivity and profitability (IBGE, 2018). These characteristics increase the risk of agricultural abandonment (Resende et al., 2016; Simões et al., 2019) and necessitate strategies aimed at increasing productivity (Ferenhof et al., 2019).

Inclusion of grains in lactating cow diets increases milk production (Bath, 1985; Llanos et al., 2018; Ru-

Received March 5, 2020.

Accepted July 13, 2020.

*Corresponding author: ferencistvan@gmail.com elle et al., 2018). This strategy is especially interesting in the case of dairy farms in Brazil, as the country is one of the largest global producers and exporters of corn and soybean (CONAB, 2017; ANEC, 2019). Such grains are the main sources of energy and protein in concentrate feed (Goes et al., 2013). High-grain feeding increases dry matter consumption and nutrient digestibility, leading to higher energy intake, milk production, body condition score, and milk quality (Bargo et al., 2003; Ferraretto et al., 2013; de Souza et al., 2018). From an economic point of view, the benefits of grain feeding (higher productivity) surpass the cost of grains, especially considering the higher stocking rate and profitability made possible by high productivity (Bargo et al., 2003; Resende et al., 2016; Llanos et al., 2018). Although it is known that grain feeding has a positive relationship with economic growth, a considerable number of Brazilian dairy farmers do not adopt cost or milk management practices, impairing analysis of economic efficiency (Paixão et al., 2017; Zimpel et al., 2017; Bánkuti et al., 2020). Because of farmers' lack of information or bounded rationality (Williamson, 1985; North, 1990), it is probable that they fail to apply efficient management strategies.

In the United States and Argentina, lactating cow diets contain about $40 \%$ of concentrate, twice the amount used in Brazil. Milk productivity in these countries ranges from 7,000 to $9,000 \mathrm{~kg} / \mathrm{cow}$ per year (FAO et al., 2014), 4 times higher than that achieved in Brazil $(1,963 \mathrm{~kg} /$ cow per year; IBGE, 2018). Thus, although Brazil ranks among the world's largest milk producers, there is much room for improvement.

Nutrition management is crucial to increase milk production per cow (Nicholson et al., 2018). It is an important factor for competitiveness and profitability (Resende et al., 2016; Llanos et al., 2018; Simões et al., 2019). Dairy farmers who do not apply nutritional strategies are more likely to have poor economic results and, therefore, have a greater chance of leaving the market (Resende et al., 2016; Simões et al., 2019).

In addition to increasing productivity, grain feeding can contribute to reducing environmental effects 
(Wirsenius et al., 2010; Mottet et al., 2017). However, it must be considered that high-grain diets can lead to health problems, such as subacute ruminal acidosis, decreasing cow productivity (NRC, 2001; Bramley et al., 2008; Humer et al., 2018). Care must be taken when opting for high-grain feeding. Silva et al. (2019) argued that, in Brazil, because dairy cows are generally fed high amounts of fiber, the risk of subacute ruminal acidosis is very low. The authors considered that dairy farmers can benefit from the increase in milk yield with high-grain feeding.

Many studies have investigated the effects of grain feeding on milk productivity (Bargo et al., 2003; Hills et al., 2015; Llanos et al., 2018) and environmental sustainability (Jiao et al., 2014; Mottet et al., 2017), but few have assessed what determines farmers' decision to include grains in the diet of lactating cows.

The theory of planned behavior (TPB) has been used to understand the socio-psychological factors influencing the decisions and behaviors of individuals (Ajzen, 1991). The TPB considers that intentions precede behavior (Ajzen, 1991). Within the TPB framework, intention is determined by 3 central socio-psychological constructs: attitude, perceived behavioral control, and subjective norms. Attitude is a favorable or unfavorable disposition toward a particular behavior. Perceived behavioral control refers to an individual's confidence in performing a behavior. Subjective norms are social pressures to perform a behavior. Therefore, the stronger the attitude, perceived behavioral control, and subjective norms, the stronger an individual's intention to perform a certain behavior (Ajzen, 1991; Wauters et al., 2010; Borges et al., 2016).

In the field of agriculture, TPB was used to understand the adoption of conservation practices (Borges and Lansink, 2016; van Dijk et al., 2016; Jiang et al., 2018), farmers' business decisions (Stojcheska et al., 2016; Senger et al., 2017; Daxini et al., 2018), and actions related to animal health and welfare (de Lauwere et al., 2012; Sok et al., 2016; Borges et al., 2019). However, to the best of our knowledge, there are no studies focused on understanding dairy farmers' decisions to use high levels of grains in dairy cow diets. We sought to answer the question, "What socio-psychological factors influence farmers' intention to adopt highgrain feeding?" by identifying the effect of attitudes, perceived behavioral control, and subjective norms on dairy farmers' decisions. In this study, we adopted a TPB-based approach to measure the intention of dairy farmers to increase the level of grains (soybean, maize, or grain-based concentrate) in lactating cow diets by at least $1 \mathrm{~kg}$ within the next year. According to TPB, farmers are more likely to increase grain feeding if they
(1) regard it as a positive practice, (2) feel capable of feeding high-grain diets to their cows, and (3) perceive a normative pressure to adopt high-grain diets. On the basis of these considerations, we formulated the following hypotheses: $H_{1}$, attitude positively influences farmers' intention toward high-grain feeding; $H_{2}$, perceived behavioral control positively influences farmers' intention toward high-grain feeding, and $H_{3}$, subjective norms positively influence farmers' intention toward high-grain feeding.

The sample included farmers from different municipalities in the state of Paraná, Brazil. With a milk production of 4.4 million tonnes, Paraná is the thirdlargest milk producer in the country (IBGE, 2018). Farmers were selected by convenience and snowball sampling (Yabe et al., 2015). Dairy farms were identified through information obtained from official technical assistance and rural extension agencies. The first farmers interviewed indicated others who might have been willing to participate in the research. Farmers were informed of the research objectives, and those who agreed to take part in the study were asked to fill out the questionnaire. A total of 150 farmers were interviewed from June to August 2019. The questionnaire was administered in person on the farm by the first author. A protocol was applied to minimize the influence of the interviewer on farmers' answers. The questionnaire comprised variables on production performance, sociodemographic characteristics, and TPB constructs. Items related to TPB constructs, including intention (INT), attitude (ATT), perceived behavioral control (PBC), and subjective norm (SN), were rated on a 5-point Likert scale from 1 to 5 (Table 1; Ajzen, 2011; Borges et al., 2019) and analyzed according to the theoretical method and questionnaire model proposed for TPB (Ajzen, 1991; Fishbein and Ajzen, 2010). Such items were randomly distributed in the questionnaire to avoid that farmers' answers were influenced by the items. The TPB items were developed considering the focus of the study (farmers' behavior toward high-grain feeding), as performed by previous studies (Daxini et al., 2018; Jiang et al., 2018; Borges et al., 2019).

Data were collected using a tablet and the QuickTapSurvey software (QuickTapSurvey, 2019). Farmers were not identified by name, address, or any other type of information. Each farmer was identified in the data bank by a number. Prior to data collection, the questionnaire was tested with 10 farmers, but substantial revisions were not necessary.

Prior to partial least squares structural equation modeling (PLS-SEM), the assumptions of multivariate normality and multicollinearity between constructs were verified. The data showed deviation from normal- 
ity, but this was not a problem for model estimation because PLS-SEM does not require data to be normally distributed (Hair et al., 2014).

Descriptive statistics were used to characterize the sample and describe grain feeding practices. Results are presented as mean \pm standard deviation. The PLSSEM was used to assess the effect of attitude, perceived behavioral control, and subjective norms on the intention of farmers to adopt high-grain feeding. All items presented in Table 1 were used as reflective indicators (Ajzen, 1991; Hair et al., 2014).

The PLS-SEM is composed of 2 submodels: a measurement model and a structural model. Using this 2-stage approach (Chin, 2010), we first confirmed the reliability and validity of the measurement model by analyzing indicator reliability, convergent reliability, internal consistency reliability, and discriminant validity. The thresholds used in this study were based on Hair et al. (2014) and Chin (2010) and are as follows: for indicator reliability, factor loadings $>0.7$, Cronbach's $\alpha$ $>0.7$, and Spearman's rho $>0.7$; for convergent validity, average variance extracted $>0.5$; and for internal consistency, composite reliability $>0.7$. Discriminant validity was assessed by examining cross-loadings (loading on a given factor must be higher than the loading on other factors, with a cut-off value of 0.70 ), the Fornell-Larcker criterion (the square root of the average variance extracted of a construct should be greater than the correlations of the other latent constructs), and the heterotrait-monotrait ratio of correlations. The structural model was evaluated by assessing the variance inflation factor (VIF, <4.00), coefficient of determination $\left(R^{2}\right)$, effect size, predictive relevance (blindfolding method), and path coefficients (Hair et al., 2014). The significance of each path coefficient was determined using a bootstrapping procedure with 500 subsamples (Hair et al., 2014). Analyses were carried out using SmartPLS (https://www.smartpls.com/).

The sample consisted of 150 farmers, most of whom were male (80\%). Farmers had a mean age of $48.70 \pm$ $13.10 \mathrm{yr}, 8.60 \pm 3.80 \mathrm{yr}$ of schooling, and $21.60 \pm 14.30$ yr of experience. Lactating cows were fed, on average, $4.67 \pm 2.27 \mathrm{~kg}$ of grains during $11.68 \pm 1.56 \mathrm{mo} / \mathrm{yr}$.

The intention to increase grain feeding was medium to low. Most respondents $(>60 \%)$ rated INT items 3 or lower on the 5-point Likert scale. Farmers' attitude toward increasing the use of grains was mainly unfavorable; about half of respondents rated ATT items 2 or 1.

Table 1. Items and scales used to measure theory of planned behavior constructs for high-grain feeding

\begin{tabular}{|c|c|c|}
\hline Construct $^{1}$ & Item & Scale $^{2}$ \\
\hline $\mathrm{INT}_{2}$ & $\begin{array}{l}\text { How strong is your intention to increase the level of grains in lactating cow diets } \\
\text { in the next year? }\end{array}$ & Very weak/very strong \\
\hline $\mathrm{INT}_{3}$ & $\begin{array}{l}\text { How likely are you to increase the level of grains in lactating cow diets in the } \\
\text { next year? }\end{array}$ & Very unlikely/very likely \\
\hline $\mathrm{INT}_{4}$ & Do you plan to increase the level of grains in lactating cow diets in the next year? & Definitely not/definitely yes \\
\hline $\mathrm{ATT}_{2}$ & $\begin{array}{l}\text { How advantageous is it for you to increase the level of grains in lactating cow } \\
\text { diets in the next year? }\end{array}$ & Very disadvantageous/very advantageous \\
\hline $\mathrm{ATT}_{3}$ & $\begin{array}{l}\text { How necessary is it to increase the level of grains in lactating cow diets in the } \\
\text { next year? }\end{array}$ & $\begin{array}{l}\text { Completely unnecessary/completely } \\
\text { necessary }\end{array}$ \\
\hline $\mathrm{ATT}_{4}$ & $\begin{array}{l}\text { How important is it to increase the level of grains in lactating cow diets in the } \\
\text { next year? }\end{array}$ & Very unimportant/very important \\
\hline $\mathrm{PBC}_{1}$ & $\begin{array}{l}\text { Would you have sufficient knowledge to increase the level of grains in lactating } \\
\text { cow diets in the next year? }\end{array}$ & Definitely not/definitely yes \\
\hline $\mathrm{PBC}_{4}$ & $\begin{array}{l}\text { Increasing the level of grains in lactating cow diets in the next year is completely } \\
\text { up to you. }\end{array}$ & Strongly disagree/strongly agree \\
\hline $\mathrm{PBC}_{5}$ & $\begin{array}{l}\text { Increasing the level of grains in lactating cow diets in the next year is something } \\
\text { under your control. }\end{array}$ & Strongly disagree/strongly agree \\
\hline $\mathrm{SN}_{1}$ & $\begin{array}{l}\text { Do most people who are important to you believe that you should increase the } \\
\text { level of grains in lactating cow diets in the next year? }\end{array}$ & Definitely not/definitely yes \\
\hline $\mathrm{SN}_{2}$ & $\begin{array}{l}\text { Do most people whose opinion you value approve that you increase the level of } \\
\text { grains in lactating cow diets in the next year? }\end{array}$ & Definitely not/definitely yes \\
\hline $\mathrm{SN}_{3}$ & $\begin{array}{l}\text { Do you think that most farmers who are like you are going to increase the level of } \\
\text { grains in lactating cow diets in the next year? }\end{array}$ & Definitely not/definitely yes \\
\hline
\end{tabular}


Table 2. Results of the structural model ${ }^{1}$

\begin{tabular}{llcccccrrr}
\hline Hypothesis & Path $^{2}$ & Std $\beta$ & SE & $\mid t$-value & Decision & $f^{2}$ & $q^{2}$ & 95\% CI LL & $95 \%$ CI UL \\
\hline$H_{1}$ & ATT $\rightarrow$ INT & 0.73 & 0.07 & $11.04^{* *}$ & Accept & 0.63 & 0.41 & 0.61 \\
$H_{2}$ & PBC $\rightarrow$ INT & 0.11 & 0.06 & $1.77^{*}$ & Accept & 0.01 & 0.01 & 0.01 \\
$H_{3}$ & SN $\rightarrow$ INT & 0.07 & 0.08 & 0.97 & Reject & 0.00 & 0.01 & -0.06 & 0.20 \\
\hline
\end{tabular}

${ }^{1} \operatorname{Std} \beta=$ standardized $\beta ; \mathrm{LL}=$ lower limit; UL $=$ upper limit.

${ }^{2} \mathrm{INT}=$ intention; ATT $=$ attitude; $\mathrm{PBC}=$ perceived behavioral control; $\mathrm{SN}=$ subjective norm.

${ }^{*} P<0.10$. ${ }^{* *} P<0.01$.

The PBC items were rated 3 or lower by most farmers, indicating that they had a moderately low perceived behavioral control over the adoption of high-grain feeding. The social pressure felt by farmers to adopt this nutrition management strategy was also medium to low: SN items were rated 3 or lower by the majority of respondents.

Measurement model assessment led to a respecification of TPB constructs. The $\mathrm{ATT}_{3}$ and $\mathrm{ATT}_{4}$ items were removed because of the high cross-loadings, and $\mathrm{SN}_{1}$ because of the high VIF. The model was tested for reliability and discriminant validity.

After evaluating the measurement model, we tested our hypotheses using the structural model (Table 2 and Figure 1). The VIF values were below 4, indicating that there was no multicollinearity between constructs. The coefficients between ATT and INT, and PBC and INT were positive and significant, indicating that $H_{1}$ (attitude has a positive effect on farmers' intention to increase grain feeding) and $H_{2}$ (perceived behavioral control has a positive influence on farmers' intention to adopt high-grain feeding) were accepted. The coefficient between SN and INT, however, was not significant; therefore, $H_{3}$ (subjective norms have a positive influence on farmers' intention to increase grain feeding) was rejected. The effect size and predictive relevance indicated that ATT was the main determinant of INT, followed by PBC (Table 2). ATT and PBC explained $76.1 \%\left(R^{2}=0.761\right)$ of the variance in farmers' intention to adopt high-grain feeding.

Our findings may help to understand farmers' motivations to adopt a practice that can benefit the entire milk production chain. High-grain feeding has social and economic importance, as it can lead to increased production, profitability, and competitiveness (Resende et al., 2016; Bánkuti and Caldas, 2018; Llanos et al., 2018), as well as environmental effect reduction, resulting from lower methane emissions (Pereira, 2013; Jiao

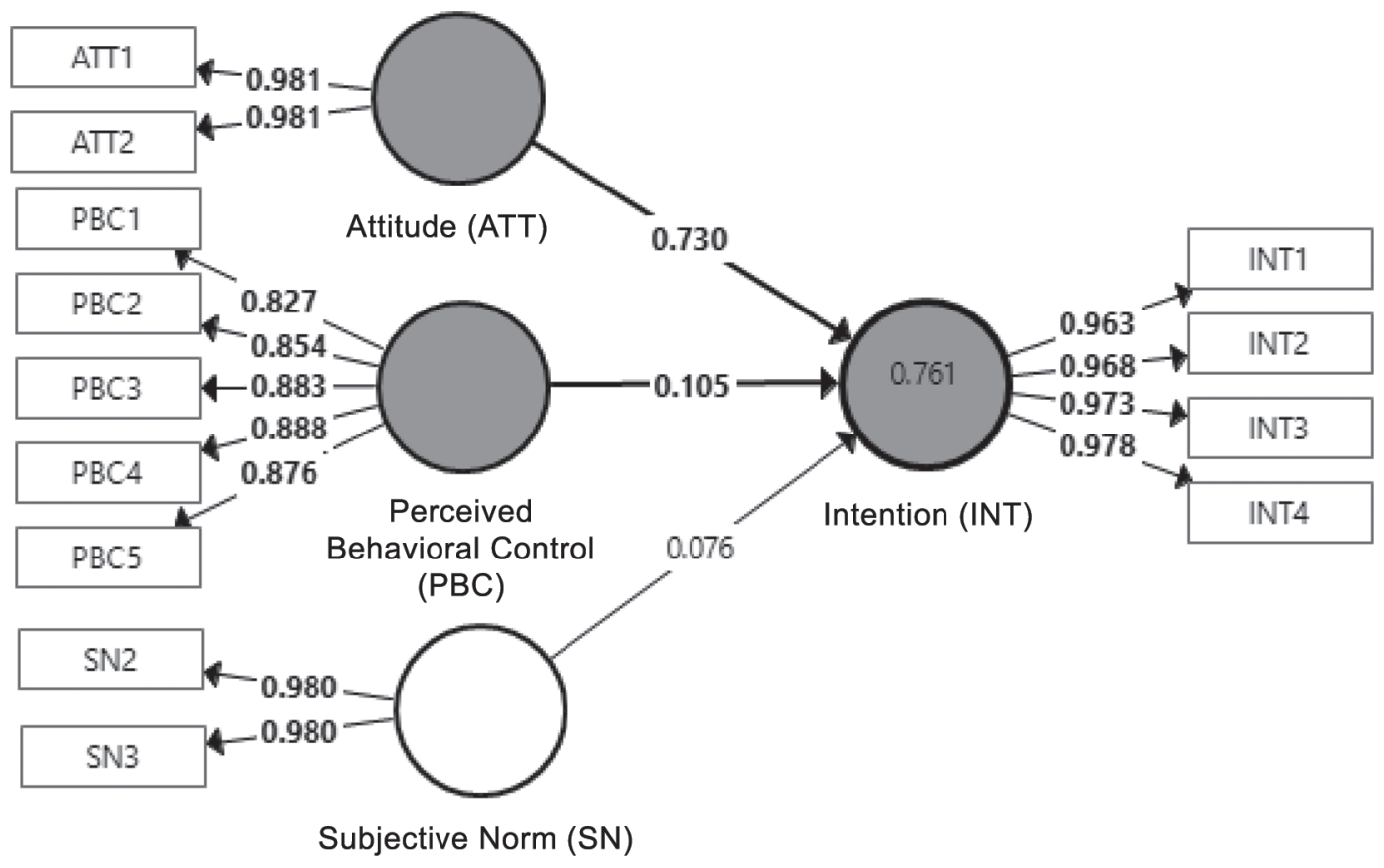

Figure 1. Standardized factor loadings and path coefficients of the final structural model based on theory of planned behavior constructs. Gray circles represent latent constructs with significant effects and white circles represent latent constructs with negligible effects. Arrows represent dependency relationships. The coefficient of determination is presented inside the circle. 
et al., 2014) and higher animal protein production efficiency (Wirsenius et al., 2010; Mottet et al., 2017). Although the risks of using high levels of grains in cow diets are low in Brazil (Silva et al., 2019), high-grain diets should be adopted with caution, as they can lead to subacute rumen acidosis and reduced animal performance (NRC, 2001; Bramley et al., 2008; Humer et al., 2018).

Attitude and PBC influenced farmers' intentions of increasing the use of grains in lactating cow diets. However, subjective norms had no significant effects. Therefore, adoption of high-grain feeding is not affected by social pressure. With respect to grain feeding, farmers act as autonomous actors who can be encouraged by information or incentives but are not influenced by what their peers think.

Other studies on the intention of farmers toward a given behavior found that subjective norms have less effect (Lalani et al., 2016) or are not significant compared with other TPB constructs (Stojcheska et al., 2016; Daxini et al., 2018; Jiang et al., 2018). Borges et al. (2019), in contrast, observed that subjective norms and perceived behavioral control have a greater effect on farmers' intentions than attitude. These heterogeneous results are expected, as the effect of each construct varies with the behavior and situation evaluated (Ajzen, 1991). We suggest that similar studies be conducted in different countries to assess the effect of each construct on farmers' decision of adopting high-grain feeding.

The fact that the correlation between SN and INT was not significant may be explained by the characteristics of the study sample. Most respondents were male, had a low level of education, and had many years of farming experience. According to Jiang et al. (2018), these are typical traits of people who pay more heed to their own perceptions and attitudes rather than to the advice of others. Jiang et al. (2018) evaluated the effect of TCP constructs on farmers' intention to reuse agricultural biomass waste for carbon reduction and found that subjective norm did not have a significant influence on farmers with the mentioned demographic characteristics.

Convenience sampling does not ensure representativeness of the study population. Furthermore, our results should be interpreted within the context of Brazilian dairy farmers and might not be generalizable. Nevertheless, our findings provide insights that can be used to develop public- and private-policy strategies to stimulate the adoption of high-grain diets for lactating cows in Brazil. The strong influence of attitude on farmers' intentions demonstrates the importance of creating information tools to disseminate the benefits of highgrain feeding. Furthermore, because of the significant influence of perceived behavioral control, interventions should focus on increasing farmers' perceived capacity, for instance, through economic incentives.

\section{ACKNOWLEDGMENTS}

This study was financed in part by the Brazilian Agency for Support and Evaluation of Graduate Education (CAPES, Finance Code 001). The authors declare that they have no conflict of interest.

\section{REFERENCES}

Ajzen, I. 1991. The theory of planned behavior. Organ. Behav. Hum. Decis. Process. 50:179-211. https://doi.org/10.1016/0749 -5978(91)90020-T.

Ajzen, I. 2011. The theory of planned behaviour: Reactions and reflections. Psychol. Health 26:1113-1127. https://doi.org/10.1080/ 08870446.2011.613995.

ANEC. 2019. Associação Nacional Dos Exportadores de Cereais. Accessed Jul. 1, 2019. www.anec.com.br.

Bánkuti, F. I., and M. M. Caldas. 2018. Geographical milk redistribution in Paraná State, Brazil: Consequences of institutional and market changes. J. Rural Stud. 64:63-72. https://doi.org/10.1016/ j.jrurstud.2018.10.004.

Bánkuti, F. I., R. C. Prizon, J. C. Damasceno, M. M. De Brito, M. S. S. Pozza, and P. G. L. Lima. 2020. Farmers' actions toward sustainability : A typology of dairy farms according to sustainability indicators. Animal 14:s417-s423. https://doi.org/10.1017/ S1751731120000750.

Bargo, F., L. D. Muller, E. S. Kolver, and J. E. Delahoy. 2003. Invited review: Production and digestion of supplemented dairy cows on pasture. J. Dairy Sci. 86:1-42. https://doi.org/10.3168/jds.S0022 -0302(03)73581-4.

Bath, D. L. 1985. Nutritional requirements and economics of lowering feed costs. J. Dairy Sci. 68:1579-1584. https://doi.org/10.3168/jds .S0022-0302(85)80996-6.

Borges, J. A. R., C. H. F. Domingues, F. R. Caldara, N. P. da Rosa, I. Senger, and D. G. F. Guidolin. 2019. Identifying the factors impacting on farmers' intention to adopt animal friendly practices. Prev. Vet. Med. 170:104718. https://doi.org/10.1016/j.prevetmed .2019.104718.

Borges, J. A. R., and A. G. J. M. Oude Lansink. 2016. Identifying psychological factors that determine cattle farmers' intention to use improved natural grassland. J. Environ. Psychol. 45:89-96. https:/ /doi.org/10.1016/j.jenvp.2015.12.001.

Borges, J. A. R., L. W. Tauer, and A. G. J. M. Oude Lansink. 2016. Using the theory of planned behavior to identify key beliefs underlying Brazilian cattle farmers' intention to use improved natural grassland: A MIMIC modelling approach. Land Use Policy 55:193203. https://doi.org/10.1016/j.landusepol.2016.04.004.

Bramley, E., I. J. Lean, W. J. Fulkerson, M. A. Stevenson, A. R. Rabiee, and N. D. Costa. 2008. The definition of acidosis in dairy herds predominantly fed on pasture and concentrates. J. Dairy Sci. 91:308-321. https://doi.org/10.3168/jds.2006-601.

Chin, W. W. 2010. How to Write Up and Report PLS Analyses. V. Esposito Vinzi, W. W. Chin, J. Henseler, and H. Wang, ed. Springer Berlin Heidelberg, Berlin, Germany.

CONAB. 2017. Acompanhamento da safra brasileira: grãos - Safra. 2016/17 4:1-158. Accessed May 11, 2019. http://www.conab.gov .br.

Daxini, A., C. O'Donoghue, M. Ryan, C. Buckley, A. P. Barnes, and K. Daly. 2018. Which factors influence farmers' intentions to adopt nutrient management planning? J. Environ. Manage. 224:350-360. https://doi.org/10.1016/j.jenvman.2018.07.059.

de Lauwere, C., M. van Asseldonk, J. van't Riet, J. de Hoop, and E. ten Pierick. 2012. Understanding farmers' decisions with regard to animal welfare: The case of changing to group housing for 
pregnant sows. Livest. Sci. 143:151-161. https://doi.org/10.1016/ j.livsci.2011.09.007.

de Souza, R. A., R. J. Tempelman, M. S. Allen, W. P. Weiss, J. K. Bernard, and M. J. Vandehaar. 2018. Predicting nutrient digestibility in high-producing dairy cows. J. Dairy Sci. 101:1123-1135. https://doi.org/10.3168/jds.2017-13344.

FAO (Food and Agriculture Organization of the United Nations), International Dairy Federation, and IFCN Dairy Research Network. 2014. World Mapping of Animal Feeding Systems in the Dairy Sector. FAO, IDF, and IFCN, Rome, Italy.

Ferenhof, H. A., A. Bonamigo, A. Da Cunha, R. Tezza, and F. A. Forcellini. 2019. Relationship between barriers and key factors of dairy production in Santa Catarina, Brazil. Br. Food J. 121:304319. https://doi.org/10.1108/BFJ-07-2018-0424.

Ferraretto, L. F., P. M. Crump, and R. D. Shaver. 2013. Effect of cereal grain type and corn grain harvesting and processing methods on intake, digestion, and milk production by dairy cows through a meta-analysis. J. Dairy Sci. 96:533-550. https://doi.org/10.3168/ jds.2012-5932.

Fishbein, M., and I. Ajzen. 2010. Predicting and Changing Behavior: The Reasoned Action Approach. Psychology Press, New York, NY.

Goes, R. H. T. B., L. H. X. da Silva, and K. A. de Souza. 2013. Alimentos e Alimentação Animal. Editora UFGD, Dourados-MS.

Hair, J. F. Jr., M. Sarstedt, L. Hopkins, and V. G. Kuppelwieser. 2014. Partial least squares structural equation modeling (PLS-SEM): An emerging tool in business research. Eur. Bus. Rev. 26:106-121. https://doi.org/10.1108/EBR-10-2013-0128.

Hills, J. L., W. J. Wales, F. R. Dunshea, S. C. Garcia, and J. R. Roche. 2015. Invited review: An evaluation of the likely effects of individualized feeding of concentrate supplements to pasture-based dairy cows. J. Dairy Sci. 98:1363-1401. https://doi.org/10.3168/ jds.2014-8475.

Humer, E., R. M. Petri, J. R. Aschenbach, B. J. Bradford, G. B. Penner, M. Tafaj, K. Südekum, and Q. Zebeli. 2018. Invited review: Practical feeding management recommendations to mitigate the risk of subacute ruminal acidosis in dairy cattle. J. Dairy Sci. 101:872-888. https://doi.org/10.3168/jds.2017-13191.

IBGE. 2018. Instituto brasileiro de geografia e estatística - Produção da Pecuária Municipal. Accessed Aug. 10, 2019. https://biblioteca .ibge.gov.br/visualizacao/periodicos/84/ppm_2018_v46_br informativo.pdf.

Jiang, L., J. Zhang, H. H. Wang, L. Zhang, and K. He. 2018. The impact of psychological factors on farmers' intentions to reuse agricultural biomass waste for carbon emission abatement. J. Clean. Prod. 189:797-804. https://doi.org/10.1016/j.jclepro.2018.04.040.

Jiao, H. P., A. J. Dale, A. F. Carson, S. Murray, A. W. Gordon, and C. P. Ferris. 2014. Effect of concentrate feed level on methane emissions from grazing dairy cows. J. Dairy Sci. 97:7043-7053. https:/ /doi.org/10.3168/jds.2014-7979.

Lalani, B., P. Dorward, G. Holloway, and E. Wauters. 2016. Smallholder farmers' motivations for using Conservation Agriculture and the roles of yield, labour and soil fertility in decision making. Agric. Syst. 146:80-90. https://doi.org/10.1016/j.agsy.2016.04.002.

Llanos, E., L. Astigarraga, and V. Picasso. 2018. Energy and economic efficiency in grazing dairy systems under alternative intensification strategies. Eur. J. Agron. 92:133-140. https://doi.org/10.1016/j .eja.2017.10.010.

Mottet, A., C. de Haan, A. Falcucci, G. Tempio, C. Opio, and P. Gerber. 2017. Livestock: On our plates or eating at our table? A new analysis of the feed/food debate. Glob. Food Secur. 14:1-8. https: //doi.org/10.1016/j.gfs.2017.01.001.

Nicholson, C., A. Simões, A. LaPierre, and M. Van Amburgh. 2018. Modeling complex problems with system dynamics: Applications in animal agriculture. J. Anim. Sci. 96(suppl_3):83. https://doi .org/10.1093/jas/sky404.183.

North, D. C. 1990. The behavioral assumptions in a theory of institutions. Pages 17-27 in Political Economy of Institutions and Decisions. J. Alt and D. North, ed. Cambridge University Press, Cambridge, UK.
NRC (National Research Council). 2001. Nutrient Requirements of Dairy Cattle. 7th ed. The National Academies Press, Washington, $\mathrm{DC}$

Paixão, M. G., M. A. Lopes, G. M. da Costa, G. N. de Souza, L. R. de Abreu, and S. M. Pinto. 2017. Milk quality and financial management at different scales of production on dairy farms located in the south of Minas Gerais state, Brazil. Rev. Ceres 64:213-221. https: //doi.org/10.1590/0034-737x201764030001.

Pereira, L. G. R. 2013. Métodos de avaliação e estratégias de mitigação de metano entérico em ruminantes. Rev. Colomb. Cienc. Pecu. 26:264-277.

QuickTapSurvey. 2019. QuickTapSurvey - Data Collection Software. Accessed May 11, 2019. https://www.quicktapsurvey.com/.

Resende, J. C., A. F. Freitas, R. A. N. Pereira, H. C. M. Silva, and M. N. Pereira. 2016. Determinantes de lucratividade em fazendas leiteiras de Minas Gerais. Arq. Bras. Med. Vet. Zootec. 68:1053-1061. https://doi.org/10.1590/1678-4162-8220.

da Rocha, D. T., J. C. de Resende, and P. C. Martins. 2018. Evolução Tecnológica da Atividade Leiteira no Brasil: Uma Visão a Partir do Sistema de Produção da Embrapa Gado de Leite. Embrapa Gado Leite, Juiz de Fora, MG, Brazil

Ruelle, E., L. Delaby, M. Wallace, and L. Shalloo. 2018. Using models to establish the financially optimum strategy for Irish dairy farms. J. Dairy Sci. 101:614-623. https://doi.org/10.3168/jds.2017 $-12948$.

Senger, I., J. A. R. Borges, and J. A. D. Machado. 2017. Using the theory of planned behavior to understand the intention of small farmers in diversifying their agricultural production. J. Rural Stud. 49:32-40. https://doi.org/10.1016/j.jrurstud.2016.10.006.

Silva, D. P., A. M. Pedroso, M. C. S. Pereira, G. P. Bertoldi, D. H. M. Watanabe, A. C. B. Melo, and D. D. Millen. 2019. Survey of management practices used by Brazilian dairy farmers and recommendations provided by 43 dairy cattle nutritionists. Can. J. Anim. Sci. 99:890-904. https://doi.org/10.1139/cjas-2018-0004.

Simões, A. R. P., C. F. Nicholson, A. M. Novakovic, and R. M. Protil. 2019. Dynamic impacts of farm-level technology adoption on the Brazilian dairy supply chain. Int. Food Agribus. Manag. Rev. 23:71-84. https://doi.org/10.22434/IFAMR2019.0033.

Sok, J., H. Hogeveen, A. R. W. Elbers, and A. G. J. M. Oude Lansink. 2016. Using farmers' attitude and social pressures to design voluntary Bluetongue vaccination strategies. Prev. Vet. Med. 133:114119. https://doi.org/10.1016/j.prevetmed.2016.09.016.

Martinovska Stojcheska, A. M., A. Kotevska, N. Bogdanov, and A. Nikolić. 2016. How do farmers respond to rural development policy challenges? Evidence from Macedonia, Serbia and Bosnia and Herzegovina. Land Use Policy 59:71-83. https://doi.org/10.1016/j .landusepol.2016.08.019.

van Dijk, W. F. A., A. M. Lokhorst, F. Berendse, and G. R. de Snoo. 2016. Factors underlying farmers' intentions to perform unsubsidised agri-environmental measures. Land Use Policy 59:207-216. https://doi.org/10.1016/j.landusepol.2016.09.003.

Wauters, E., C. Bielders, J. Poesen, G. Govers, and E. Mathijs. 2010 Adoption of soil conservation practices in Belgium: An examination of the theory of planned behaviour in the agri-environmental domain. Land Use Policy 27:86-94. https://doi.org/10.1016/j .landusepol.2009.02.009.

Williamson, O. E. 1985. The Economic Institutions of Capitalism. The Free Press, New York.

Wirsenius, S., C. Azar, and G. Berndes. 2010. How much land is needed for global food production under scenarios of dietary changes and livestock productivity increases in 2030? Agric. Syst. 103:621638. https://doi.org/10.1016/j.agsy.2010.07.005.

Yabe, M. T., F. I. Bankuti, J. C. Damasceno, and M. M. de Brito. 2015. Characteristics of milk production systems and feed strategies for dairy cows in the North and Northwest of Paraná State. Semin. Agrar. 36(6Supl2):4469-4479. https://doi.org/10.5433/ 1679-0359.2015v36n6Supl2p4469.

Zimpel, R., F. I. Bánkuti, M. A. Zambom, K. C. Kuwahara, and S. M. S. Bánkuti. 2017. Characteristics of the dairy farmers who perform financial management in Paraná State, Brazil. Rev. Bras. Zootec. 46:421-428. https://doi.org/10.1590/s1806-92902017000500008. 